\title{
Effect of Cereal Grains on Spawn Development and Different Substrates on Growth and Yield of Hypsizygus ulmarius
}

\author{
Dheeraj Baghel*, C.S. Shukla, H.K. Singh, Praveen Banvasi and Varsha Kerketta \\ Department of Plant Pathology, College of Agriculture, I.G.K.V., Raipur (C.G.), India \\ *Corresponding author
}

\section{A B S T R A C T}

Ke y w o r d s
Mushroom,
Hypsizygus
ulmarius, Mycelial
growth, Spawn run
period, Pinhead
initiation and yield
and biological
efficiency
Article Info
Accepted:
15 April 2020
Available Online:
10 May 2020

Since ancient times, mushrooms have been considered as a special kind of food. Blue oyster mushroom is a novel species with very large fruit body, blue coloured pinheads becoming light white on maturity, high yielder, palatable with meaty flavour and attractive keeping quality. Different types of cereal grains i.e. maize, sorghum, bajra, wheat and paddy were taken to see their effect on spawn development and Different substrates i.e. wheat straw, paddy straw, mustard straw, sesamum straw and pigeon pea straw significantly influenced the spawn run period, pinhead initiation and yield of $H$. ulmarius. Sorghum grains were found to be most suitable for spawn development of $H$. ulmarius, it took significantly less time (10.4 days). However, spawn development was delayed in maize (13.4 days) and wheat grains (14.6 days). The sorghum grains were fully covered by white mycelial growth and all grains were tightly intact with each other where other grains were observed mycelia growth on all grains but they were easily disturb. Spawn run was significantly earlier found in pigeon pea straw (18.50 days). However it was significantly late noticed in paddy (21.0 days). Minimum period required for primordial initiation was significantly less in pigeon pea ( 2.75 days) followed by mustard (3.75days). The biological efficiency of $H$. ulmarius in wheat straw $(98.12 \%)$ Whereas, it was minimum with pigeon pea, mustard and sesamum straw $(64.7,66.52,70.62 \%$ respectively).

\section{Introduction}

Mushrooms have been used as food and medicine from time immemorial. Nutritious food is the basic requirement in these days. Due to population explosion, the problem of protein hunger has become more and more acute. Being a good source of quality protein, mushroom production is an alternative source to decrease malnutrition. Nutritionally, this mushroom contains $23.6 \%$ protein, $2.2 \%$ fat, $52.4 \%$ carbohydrate and $12.9 \%$ fiber on dry weight basis (Chang, 1999). Blue oyster mushroom is a novel species with very large fruit body, blue colored pinheads becoming light white on maturity, high yielder, palatable with meaty flavor and attractive keeping quality. The first stage of mushroom production is produced of strong spawns with increasing mycelium growth. It is equal to seed of higher plants. Spawn quality is counted the most important part in mushroom production (Mohammadi Goltapeh and Purjam, 2003). Grain spawn is a medium that 
is impregnated with mycelium made from a pure culture of the chosen mushroom strain, and spawn production is a fermentation process in which the mushroom mycelium increases by growing through a solid organic matrix. Although, grain spawn is currently prepared by inoculating sterilized grains with complete sterile precaution, yet small and medium size spawn- laboratories still face the problems of contamination i.e. unwanted intrusion of harmful and competing organisms in the spawn, making them useless and dangerous for mushroom production due to their potential for infecting the beds and the crop as a whole. Agricultural wastes are rich in lignincellulosic components which are difficult to breakdown, but can effectively be done mushroom cultivation. Mushrooms are fleshly fungi, sporebearing fruiting bodies which are produced above ground on soil. They often refer to fruiting body of the gill fungi, which do not contain chlorophyll like green plants and as a result cannot manufacture food by their own. They are very nutritious products that can be generated from lingo cellulosic waste materials. The bioconversion of agricultural wastes into a value added products is a good mean of their use. The property of edible mushroom fungi to convert complex organic compounds into simpler one's is used to transform the useless agricultural waste into valuable product.

\section{Materials and Methods}

\section{Effect of cereal grains on spawn development}

Different types of cereal grains i.e. maize, sorghum, bajra, wheat and paddy were taken to see their effect on spawn development of $H$. ulmarius. The above grains were processed like as clean healthy and bold grains were taken but broken and undersized grains were discarded then these were thoroughly washed and dipped in water for 6-7 hours. The soaked grains were cooked for 10-15 minutes till they become soft without rupturing of epidermis. Thereafter, the excess water was drained and grains were spread on muslin cloth so that excess moisture can be eliminated. In cooled grains, Gypsum and Calcium carbonate (2\% w/w) were mixed thoroughly. These prepared grains were filled in bottles $(250 \mathrm{ml})$ and plugged with non-absorbent cotton. Each bottle contains $250 \mathrm{~g}$ grains and sterilized at 20 lbs. psi for 2 hours. After cooling, these flasks were inoculated with equal sized mycelial bit of pure culture. Inoculated flasks were incubated at $25 \pm 2^{\circ} \mathrm{C}$ and observations were recorded when the mycelium covered the entire grains in any treatment. Three replications were kept in each treatment.

\section{Effect of different substrates}

To find out the best suitable substrate to obtain higher yield of $H$. ulmarius an experiment were conducted on different substrates i.e., paddy straw, pigeon pea straw, wheat straw, mustard straw and sesamum straw. The substrates were dipped in water (which has already mixed with $75 \mathrm{ppm}$ Carbendazim and 500ppm formaldehyde) for 14 hours as per the method described by Vijay and Sohi (1987). Thereafter, excess water was drained off the next morning and straw was spread over on sloppy, cemented floor till the moisture content of straw remained 65-70 per cent. Before spawning, formaldehyde was sprinkled on floor, and thereafter the spawn was mixed in substrates through layering method @ 10 per cent on dry weight basis of substrates. The spawned substrates were filled in poly propylene bags $(18 " \times 27 "-150$ gauges $)$ and mouth of the spawned bags was tied with nylon rope. The spawned bags were kept in mushroom growing room, where appropriate temperature $\left(25 \pm 2^{0} \mathrm{C}\right)$ and relative humidity $(80-90$ per cent) were maintained by frequently sprinkling of water on walls and floor. Five 
replications for each substrate were maintained. The observations on number of days taken for spawn run, pinhead initiation and yield per unit of straw were recorded.

All the experimental data were analyzed using completely Randomized Design (CRD) with equal and unequal replications and factorial CRD. The critical difference (C.D.) was calculated at $5 \%$ levels.

\section{Results and Discussion}

\section{Effect of cereal grains on spawn development}

There was significant difference in spawn development of $H$. ulmarius on different grains. Among the tested grains, minimum (10.4 days) period for spawn development of $H$. ulmarius was recorded in sorghum grains and it was significantly less than other grains. However, paddy took maximum (17.6 days) period for spawn development of $H$. ulmarius and followed by bajra (11.2 days), maize (13.4 days), wheat (14.6 days) grains. The sorghum grains were fully covered by white mycelial growth and all grains were tightly intact with each other, where maize grains were White mycelial, all grains were completely covered by mycelium and all grains were tightly held with each other and other grains (bajra, wheat and paddy) were observed mycelia growth on all grains but they were easily disturb.

The findings of present investigation are in agreement with Saayier and Yildiz (2004) they evaluated different grains for spawn preparation of Pleurotus spp. and noticed earlier spawn development of different Pleurotus spp. on sorghum grains. Similarly, sorghum grains were reported as best substrate for quick spawn preparation of wild pink oyster mushroom by Sawale (2004); Mathew et al., (2004), for P. sajor-caju and Chaurasia (1997) for P. columbines.

\section{Effect of different substrates on spawn run and yield}

To find out the suitable substrate, different substrate i.e. wheat straw, paddy straw, mustard straw, sesamum straw and pigeon pea straw were studied for growth and pinhead initiation and yield of $H$. ulmarius.

Different substrates significantly influenced the spawn run period, pinhead initiation and yield of $H$. ulmarius. The time required for spawn run by $H$. ulmarius varied significantly with respect to different substrate used. Spawn run was significantly earlier found in pigeon pea straw (18.50 days) than other substrates used.

However it was significantly late noticed in paddy (21.0 days) and sesamum straw and was statistically at par with each other. Mustard and wheat straw required 19.3 and 19.5 days for spawn run of $H$. ulmarius followed.

Minimum period required for primordial initiation was significantly less in pigeon pea (2.75 days) followed by mustard (3.75days) whereas maximum time taken by sesamum (4.50 days).

The fresh yield of $H$. ulmarius significantly influenced by different substrates and it was significantly higher (490.63g) recorded on wheat straw and paddy straw $(423.75 \mathrm{~g})$ and at par with each other while other substrate i.e. pigeon pea (322.38g) sesamum (332.63g) and mustard straw gave significantly less yield did not differ significantly with each other.

The biological efficiency of $H$. ulmarius in different substrates in accordance with that of fresh yield obtained from wheat straw (98.12 $\%)$ Whereas, it was minimum with pigeon pea, mustard and sesamum straw $(64.7,66.52$, $70.62 \%$ respectively) (Fig. 1-6 and Table 1 and 2). 
Table.1 Effect of different grains substrate on spawn development of H. ulmarius

\begin{tabular}{|c|c|c|c|}
\hline S.N. & Treatment & $\begin{array}{c}\text { Spawn } \\
\text { development } \\
\text { (days)* }\end{array}$ & Growth characteristics \\
\hline 1 & SORGHUM & 10.4 & $\begin{array}{l}\text { White mycelial growth on all grains and intact } \\
\text { with each other. }\end{array}$ \\
\hline 2 & BAJRA & 11.2 & $\begin{array}{l}\text { Mycelial growth was observed on all grains but } \\
\text { they were easily disturb. }\end{array}$ \\
\hline 3 & MAIZE & 13.4 & $\begin{array}{l}\text { White mycelial, all grains were completely } \\
\text { covered by mycelium and all grains were } \\
\text { tightly held with each other. }\end{array}$ \\
\hline 4 & WHEAT & 14.6 & $\begin{array}{l}\text { Mycelial growth was observed on all grains but } \\
\text { they were easily disturb. }\end{array}$ \\
\hline 5 & PADDY & 17.6 & $\begin{array}{l}\text { Mycelial growth was observed on all grains but } \\
\text { they were easily disturb. }\end{array}$ \\
\hline & SEm \pm & 0.276 & \\
\hline & CD $(5 \%)$ & 0.819 & \\
\hline
\end{tabular}

* Average of four replications

Table.2 Effect of different substrate on spawn run, Primordial initiation, yield and $\mathrm{BE}(\%)$ of $H$. ulmarius

\begin{tabular}{|c|c|c|c|c|}
\hline Substrate & $\begin{array}{c}\text { Spawn } \\
\text { run } \\
\text { (Days) }\end{array}$ & $\begin{array}{c}\text { Primordial } \\
\text { initiation } \\
\text { (Days) }\end{array}$ & $\begin{array}{c}\text { Yield in (g./500g. dry } \\
\text { substrate)* }\end{array}$ & $\begin{array}{c}\text { Biological } \\
\text { efficiency (\%) }\end{array}$ \\
\hline Pigeon pea & 18.50 & 2.75 & 322.38 & $\mathbf{6 4 . 4 7}$ \\
\hline Mustard & 19.30 & 3.75 & 353.13 & $\mathbf{7 0 . 6 2}$ \\
\hline Sesamum & 20.38 & 4.5 & 332.63 & $\mathbf{6 6 . 5 2}$ \\
\hline Wheat & 19.50 & 3.5 & 490.63 & $\mathbf{9 8 . 1 2}$ \\
\hline Paddy & 21.00 & 4.0 & 423.75 & $\mathbf{8 4 . 7 5}$ \\
\hline SEm \pm & $\mathbf{0 . 2 3}$ & $\mathbf{0 . 3 1}$ & $\mathbf{1 2 . 5 8}$ & \\
\hline CD $(\mathbf{5 \%})$ & $\mathbf{0 . 6 6}$ & $\mathbf{0 . 8 9}$ & $\mathbf{3 6 . 2 7}$ & \\
\hline
\end{tabular}

* Average of five replications 
Fig.1 Different grains substrate on spawn development of $H$. ulmarius

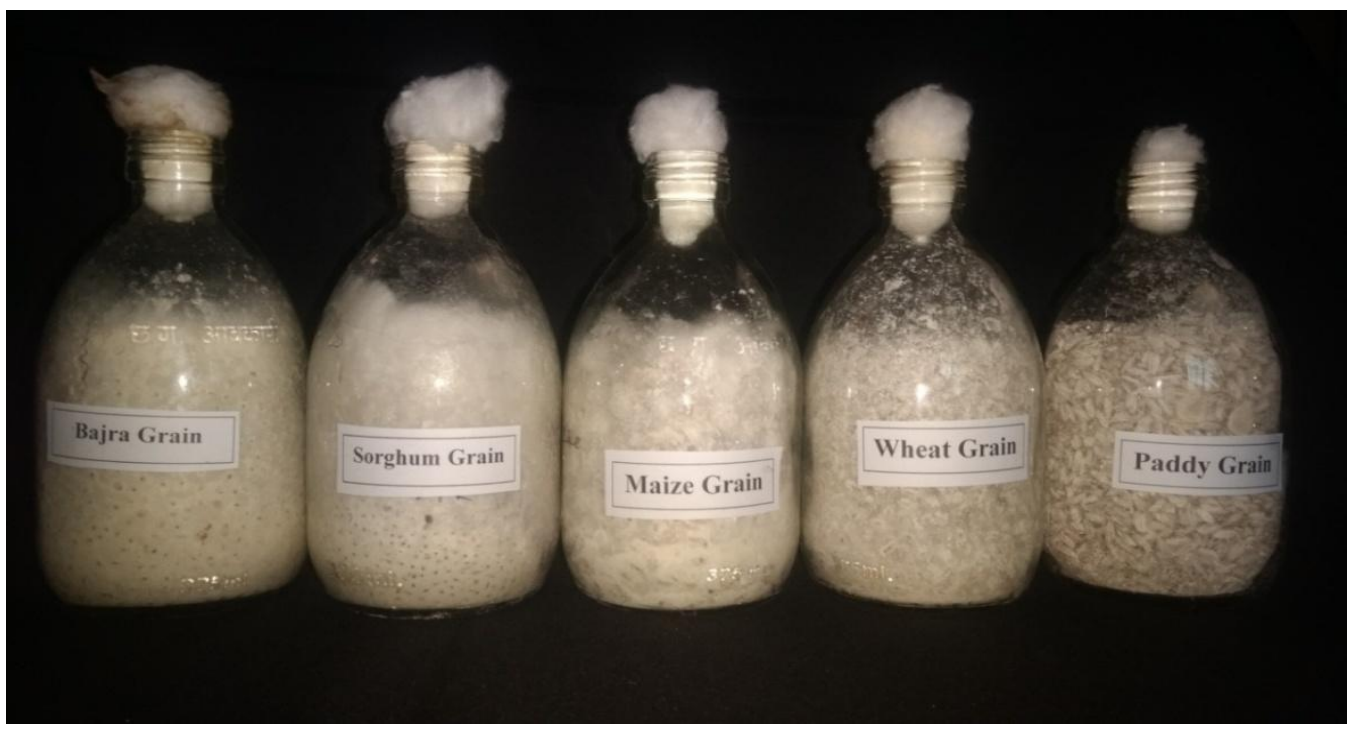

Fig.2 Effect of different substrate on spawn run and yield of $H$. ulmarius
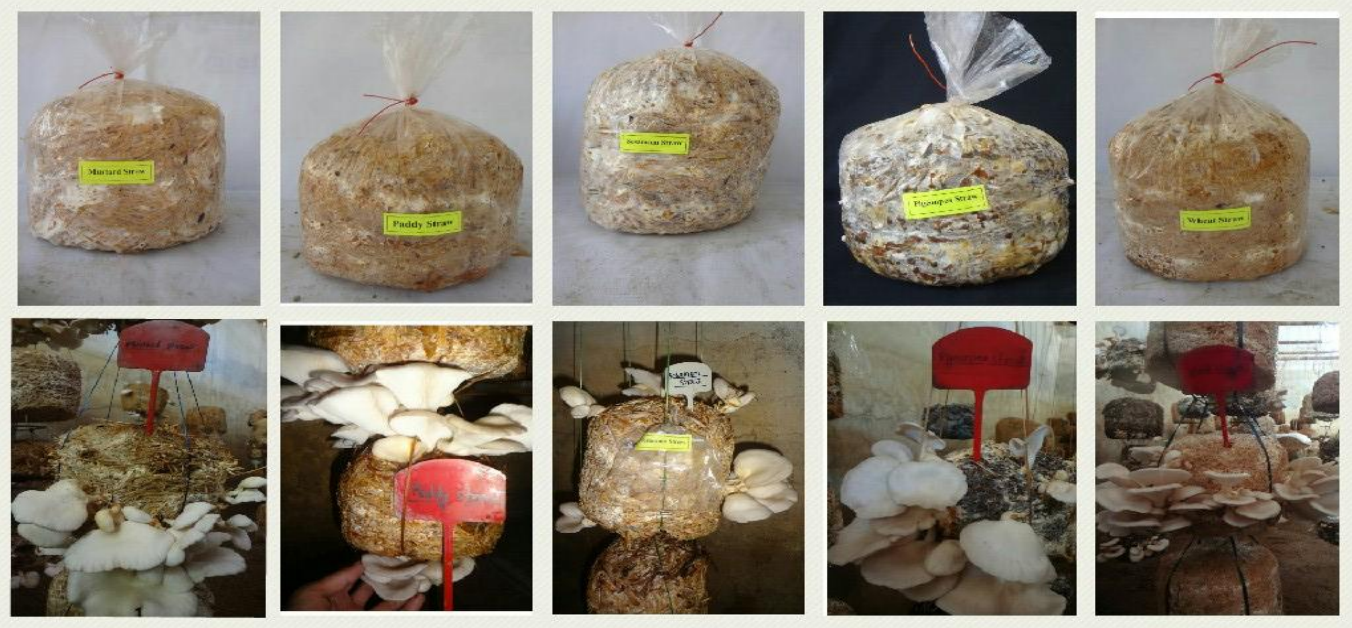

Fig.3 Effect of different grain substrate on spawn development of $H$. ulmarius

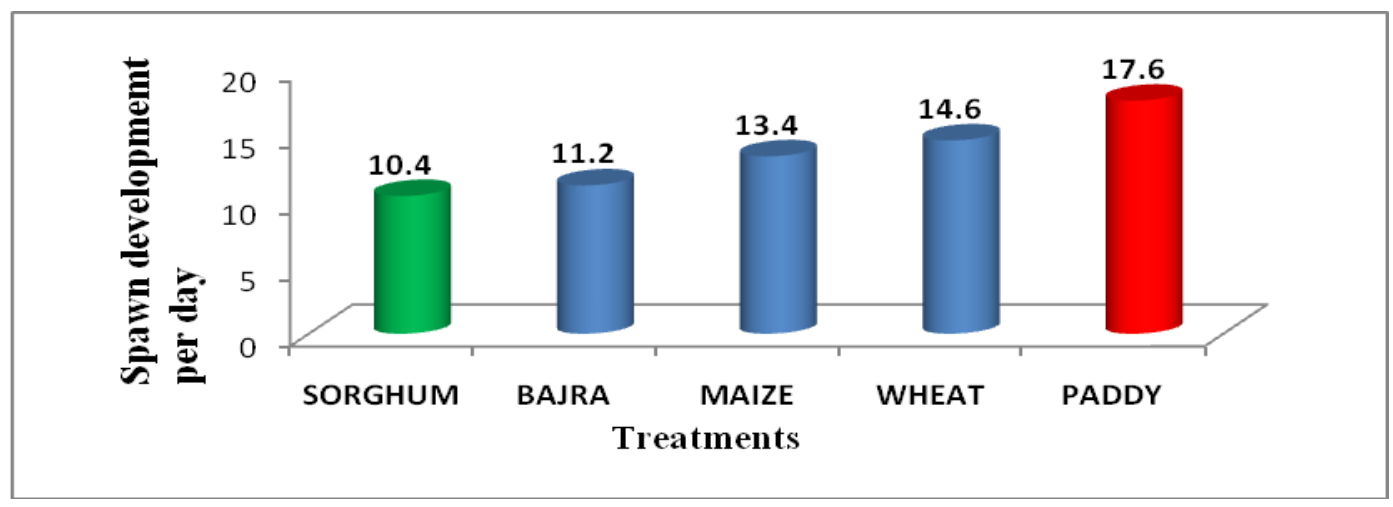


Fig.4 Effect of different substrate on spawn run of $H$. ulmarius

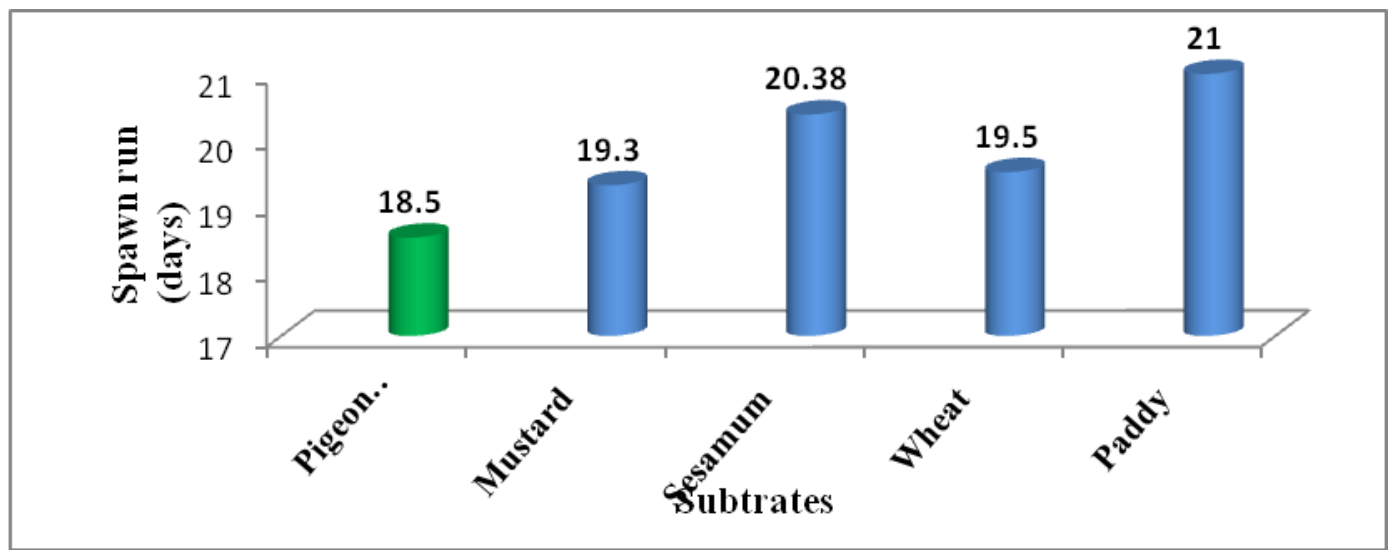

Fig.5 Effect of different substrate on primordial initiation of H. ulmarius

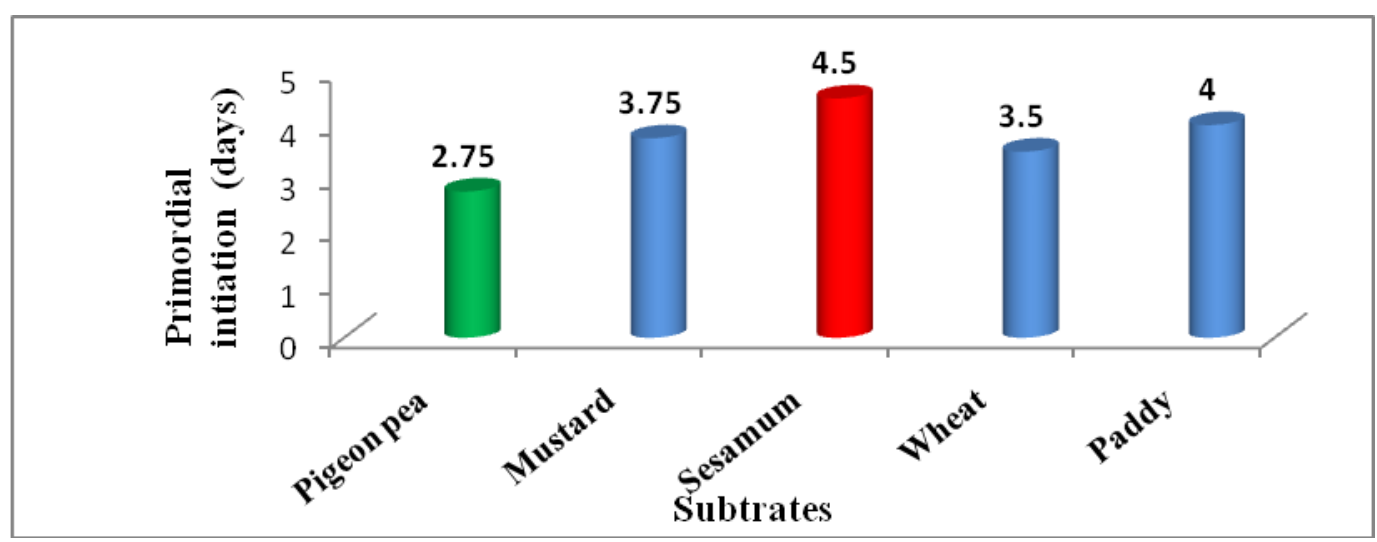

Fig.6 Fresh yields of different substrates of $H$. ulmarius

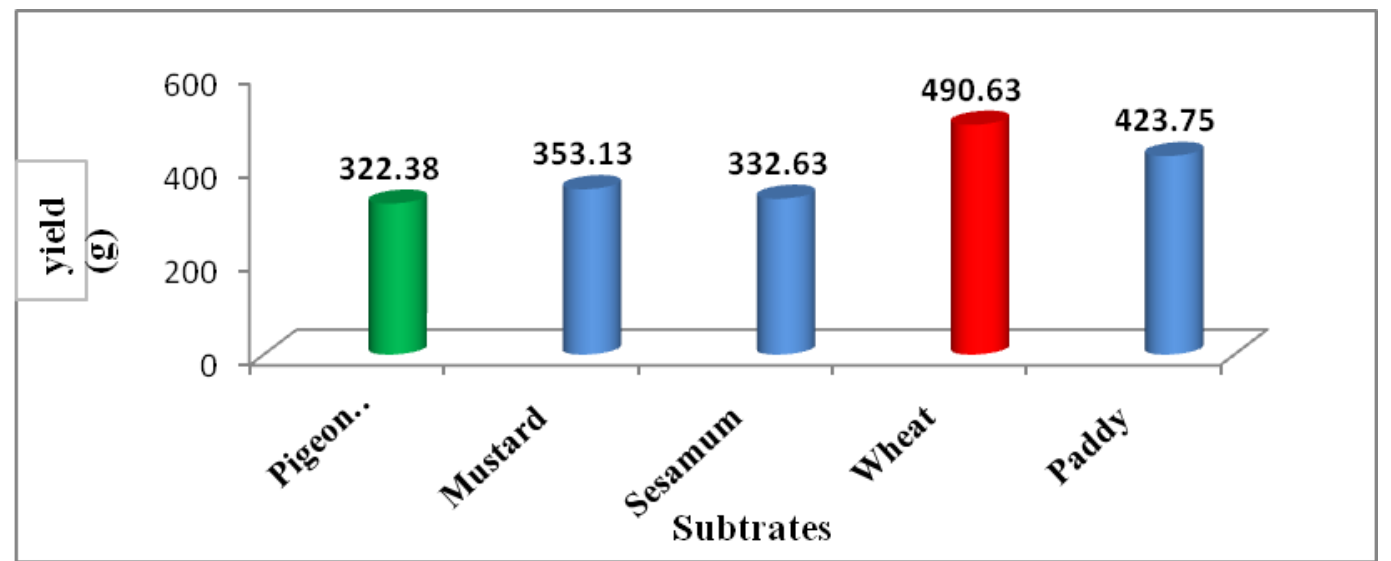


The present results are tallies with the work carried out by Iqbal et al., (2005) they cultivated oyster mushroom, Pleurotus ostreatus (local \& exotic strains) and $P$. sajarcaju on different substrates and revealed that banana leaves followed by paddy and wheat straw gave higher yield of both species. Similarly Borkar et al., (2014) evaluated locally available substrates such as paddy straw, arecanut husk, coconut husk, banana pseudostem, groundnut shells, sugarcane bagasse and wheat straw alone and in combination for growth of $P$. pulmonarius and obtained higher biological efficiency of $P$. pulmonarius on paddy straw and wheat straw substrate.

It is concluded as among different grain substrate used for spawn development, sorghum grains were found as excellent substrate for spawn preparation of $H$. ulmarius. Among the evaluated substrate wheat straw gave significantly higher maximum yield and biological efficiency.

\section{References}

Borkar, P.G., Doshi, A., Joshi, M. and Navathe, S. 2014. Suitability of various substrates for cultivation of Pleurotus pulmonarius in Konkan Region of Maharashtra. Journal of Life Sciences Research, 1(2): 51-53.

Chang, S.T. 1999. World production of cultivated edible and medicinal mushroom in 1997 with emphasis on Lentinus edodes (Berk) Sing. In China. Int. J. Med. Mushroom. 1: 291- 300.

Chaurasia, V.K., 1997. Studies on production technology of Pleurotus columbinus at Raipur. M. Sc.(Ag.) Thesis IGKV, Raipur (CG).
Elhami, B. and Ansari, N. A. 2008. Effect of Substrates of Spawn Production on Mycelium Growth of Oyster Mushroom Species. Journal of Biological Sciences, 8(2): 474-477.

Iqbal, S.M., Rauf, C.A. and Sheikh, M.I. 2005. Yield performance of oyster mushroom on different substrates. Int. J. Agri. Biol., 7(6): 900-903.

Khatri, R. K. and Agrawal, K. C. 2002. Effect of different grains and used tea leaves on spawn development of Cantharellus spp. in comparison to Pleurotus florida. J. Mycol. Pl. Pathol., 32(3): 431-432.

Kumar, P., Pal, J. and Sharma, B. M. (1997). Cultivation of Pleurotus sajor-cju on various plant wastes. Paper presented in Indian Mushroom Conference-97 at NCMRT, Solan from $10-12^{\text {th }}$ September, pp. 40 (Abstr.).

Mehetre, S.S., Dhumal, P.M., Shinde, R.B., Kale, K.D. and Magdum, S.G. 1996. Soybean straws on agro waste for mushroom cultivation. Indian farming, 46(4), pp.20-22.

Mohammadi Goltapeh, E. and E. Purjam, 2003. Principles of Mushroom Cultivation. Tarbiat Modarres University Press, UK., pp: 604.

Patil, S.S., 2012. Cultivation of Pleurotus sajorcaju on different agro wastes. Science Research Reporter, 2(3): 225-228.

Saayir, A. and Yildiz, A. 2004. Growth of mycelium of Pleurotus spp. on different grains and determination of their competition with some contaminant fungi. Acta Alimentaria, 33 (3): 249-257.

Vijay, B. and Sohi, H.S. (1987). Cultivation of oyster mushroom Pleurotus sajorcaju(Fr.). Singer on chemically sterilized wheat straw. Mush. J. tropics, 7: 67-75.

\section{How to cite this article:}

Dheeraj Baghel, C.S. Shukla, H.K. Singh, Praveen Banvasi and Varsha Kerketta. 2020. Effect of Cereal Grains on Spawn Development and Different Substrates on Growth and Yield of Hypsizygus ulmarius. Int.J.Curr.Microbiol.App.Sci. 9(05): 2175-2181.

doi: https://doi.org/10.20546/ijcmas.2020.905.248 